\title{
Temporal variation of glacial lakes since 1976 in the Great Himalayas revealed by satellite imageries
}

\author{
Nariyuki Satot, Takayuki Shiraiwał and Tomomi Yamadał* \\ † Graduate School of Environmental Earth Science, Hokkaido University, Sapporo, JAPAN \\ ¥ Institute of Low Temperature Science, Hokkaido University, Sapporo, JAPAN \\ *To whom correspondence should be addressed. E-mail: Iangmaljp@yahoo.co.jp
}

The supra-glacial lakes are abundantly formed on the glacier tongues of debris-covered valley glaciers especiallyin theeastern Great Himalayas, which may be as a result of global warming. The lakes have frequently burst and hazardous floods have happened, since the lakes are dammed by an unstable moraine formed in the Little Ice Age (Yamada 1998). The flood is called Glacier Lake Outburst Flood (GLOF). The GLOF is a new face of the natural disaster newly arising in the Himalayas in the later half of $20^{\text {th }}$ century and has been a serious problem for the socioeconomical development of Himalayan countriessuch as Nepal, India, Bhutan and China.

Is the lake still newly born? How much are the lakes expanding? By using Landsat MSS and ETM imageries, respectively taken in 1976 and 2000/2001/2002, temporal variation of thelakes during 24to 26 yearsareinvestigated in the northern and southern slopes of the Great Himalayas spreading over thelongitudebetween $85015^{\prime}$ and 91000 'E. To examinethe regional characteristics in thetemporal variation of thelakes, the northern and southern slopesare divided into threesub-regions by River Arun running from Tibet to Nepal and River Kangpu from Tibet to Sikkim. Thus the covered area are divided into six subregions, which are called North-West (NW), North-Center (NC) and North-East (NE), which sub-regions belongTibet, and SouthWest (SW, belonging eastern Nepal), South-Center (SC, eastern Nepal to western Sikkim) and South-East (SE, eastern Sikkim and Bhutan). Themoraine-dammed glacier lakesmorethan $0.01 \mathrm{~km}^{2}$ in area are extracted from the imageries due to the limitation of thespecial resolution.

The numbers and area of the glacier lakes in each subregion in 1976and 2000sareshown in Table1 Those of new lakes formed after 1976 are also shown in theTable. It is characterized that the total glacier area in the northern slope (Tibetan side) is larger than that in the southern slope, while the total number in the northern slope is less than that in southern slope, because thesizeof valleyglaciersin thenorthern slopeis remarkablylarger than that in the southern slope. The number of present glacier lakes is totally 539 with the area of $122.46 \mathrm{~km}^{2}$, which includes the count of new lakesformed after 1976. Total expansion area of thelakes amountsto be $37.47 \mathrm{~km}^{2}$, including thetotal area of 10.25 $\mathrm{km}^{2}$ for 35 lakes newly formed. Especially, the lakes in Bhutan (sub-region SE) have developed morethan two times in thearea, while 1.35 times on an average in the other sub-regions. As a result of examining the reasons of lake expansion in terms of global warmingand theinclination of topography, whereglaciers aresituated, no clear relation is found in theglobal warming, but in the topography: The gentler an inclination of topography is, the more the glacial lakes develop.

\section{Reference}

Yamada T 1998. Glacier lakeand its outburst flood in the Nepal Himalaya. Data Center for Glacier Research, Japanese Society of Snow and ice. Monograph No. 1. 96p

Table 1: Number and area of the glacier lakes in 1976 and 2000s, and also those of new lakes formed after 1976, in each sub-region.

\begin{tabular}{|c|r|r|r|r|r|r|}
\hline \multirow{2}{*}{ Sub-region } & \multicolumn{2}{|c|}{1976} & \multicolumn{2}{c|}{$2000 \mathrm{~s}$} & \multicolumn{2}{c|}{ formed after 1976 } \\
\cline { 2 - 7 } & Number & $\begin{array}{r}\text { Area } \\
\left(\mathrm{km}^{2}\right)\end{array}$ & Number & $\begin{array}{r}\text { Area } \\
\left(\mathrm{km}^{2}\right)\end{array}$ & $\begin{array}{r}\text { Number of } \\
\text { New Lake }\end{array}$ & $\begin{array}{r}\text { Area of New } \\
\text { Lake }\left(\mathrm{km}^{2}\right)\end{array}$ \\
\hline NW & 54 & 24.62 & 61 & 33.02 & 7 & 0.22 \\
\hline NC & 70 & 15.29 & 90 & 20.76 & 20 & 1.86 \\
\hline NE & 56 & 17.70 & 72 & 22.46 & 16 & 0.93 \\
\hline SW & 89 & 11.47 & 121 & 17.83 & 32 & 1.15 \\
\hline SC & 59 & 6.15 & 78 & 8.43 & 19 & 1.07 \\
\hline SE & 82 & 9.76 & 117 & 19.96 & 35 & 5.02 \\
\hline Total & 410 & 84.99 & 539 & 122.46 & 129 & 10.25 \\
\hline
\end{tabular}

